
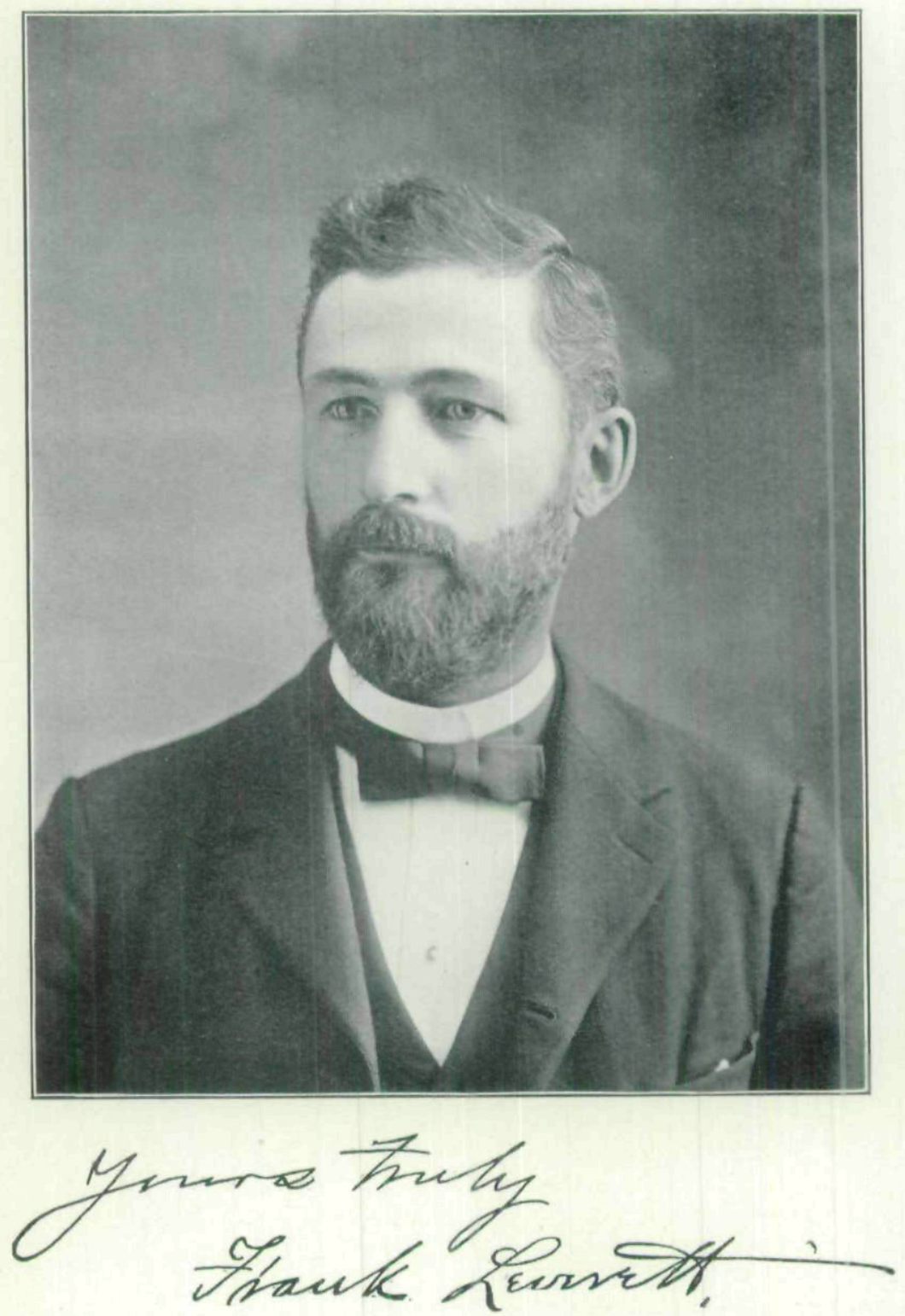

FRANK LEVERETT, ASSISTANT UNITED STATES GEOLOGIST, 


\title{
AN IOWA SCIENTIST AND HIS WORK.
}

\author{
BY CHARLES R. KEYES, PH. D,
}

At the present time the eyes of the scientific world are directed towards Iowa for the completest solutions to the problems concerning the great Ice Age. Forty years ago the glacial theory, as proposed by Agassiz, startled scientists and laymen alike. It is one of the most brilliant achievements of a century replete with scientific discoveries; it is a novelty undreamed of in all previous history; yet to-day one of the firmest tenets of modern geology.

Of late, unusual activity has developed among the students of glacial history. The body of investigators has become large and the literature voluminous. At no time and in no land has interest in any geological subject been so great as in the upper Mississippi valley during the past few years. In conducting this work no one has shown greater persistence, displayed greater energy in the field, or accomplished grander results than one of our own native Iowans, Mr. Frank Leverett.

Mr. Leverett has lived in the State so little during the decade and a half that has just passed that few of our people know that the distinguished scientist is really an Iowa production and still claims Iowa as his home. For the past few years he has resided in Denmark, Lee county, the place of his birth. But wherever in the wide world the great Ice Age is discussed, and wherever geologists are found, the name of our modest yet illustrious citizen is familiar.

There is just appearing from the government printing office, at Washington, a monograph on one of the great ice invasions in the central part of the upper Mississippi valley. It bears the title of "The Illinois Glacial Lobe," and its author is Mr. Frank Leverett. It forms a huge volume of more than 800 quarto pages, with many illustrations and maps. Altogether, it constitutes one of the most notable contributions ever made to 
glacial geology. The volume is such a noteworthy one, so elaborately put together, and so replete with information of great interest and practical importance, that only a careful perusal of it can give one any adequate idea of the vast work necessary to accomplish the undertaking. In this place only the barest abstract, as indicated by the author of this monumental tome, can be given.

The introduction defines the Illinois glacial lobe which formed the southwestern part of the greatice-field that extended from the highlands east and south of Hudson's Bay southwestward over the basins of the Great Lakes and the northcentral states as far as the Mississippi Valley. It overlapped a previously glaciated region on the southwest, whose drift was derived from an ice-field that moved southward from the central portion of the Dominion of Canada as far as the vicinity of the Missouri River. This southwestern part of the eastern ice-field, being mainly within the limits of the state of Illinois, has received the name Illinois Glacial Lobe.

In Chapter II the physical features of the region are described. The variations in altitude are set forth in a topographic map and also in tables, and the marked increase in altitudes in certain parts of the region because of drift accumulations is considered. The conspicuous reliefs of the rock surface are briefly touched upon, and the preglacial valleys receive passing notice. Profiles and maps are extended across the bed of Lake Michigan, as well as border districts, and the inequalities of the lake basin are briefly discussed.

An outline of time relations, or the glacial succession, constitutes the third chapter. A sketch of the major and minor divisions of the drift sheets and the intervals between them is accompanied by a brief explanation of the basis for the classification adopted.

Chapter IV considers the Illinoian drift sheet and its relations. The evidence that this drift sheet should be separated from the outlying and underlying drift and also from the Iowan drift is briefly set forth. A detailed description of 
the border of the Illinoian drift sheet is then given, which is followed by a description of the moraines and other drift aggregations back from the border.

Remarkable instances of the transportation of rock ledges are noted. The striæ pertaining to this invasion are discussed in some detail. The effect of this ice invasion and its drift deposits upon the outer border drainage is touched upon, but the detailed discussion of the influence of the drift upon the drainage is deferred to a later chapter. The chapter closes with a discussion of the deposits which underlie the Illinoian drift sheet.

A description of the Yarmouth soil and weathered zone which appear between the Kansan and Illinoian drift sheets, in the overlap of the latter upon the former, are described, and sections are presented which show clearly the relations to these drift sheets. The amount of erosion affected during the interglacial stage is also considered.

In the following chapter the Sangamon soil and weathered zone are similarly considered. These appear between the Illinoian drift and the overlying loess.

Of special interest is Chapter VII, on the Iowan drift sheet and associated deposits. The name Iowan was applied by Chamberlin to a sheet which is well displayed in eastern Iowa and which had been brought to notice by McGee. The chapter opens with the discussion of a drift sheet of a similar age, which was formed by the Illinois lobe, its extent, topographic expression, and structure being considered. The relation of this ice lobe, and the relation of each to the great loess deposit of the Mississippi Basin are then considered, after which the loess is discussed. The problem of the mode of deposition of the loess forms the closing topic.

Chapter VIII describes the Peorian soil and weathered zone (Toronto formation?). A marked interglacial interval between the Iowan and Wisconsin stages of glaciation may be inferred by a comparison of the outline of the ice sheet at the Iowan stage of glaciation with that of the outline at the 
culmination of the Wisconsin stage. It may also be inferred by a change in the altitude of the land, by which better drainage conditions were prevalent in the Wisconsin than in the Iowan stage.

The early Wisconsin drift sheets are the subject of Chapter IX. The Wisconsin drift is characterized by large morainic ridges and comparatively smooth intervening tillplains which have been thrown into two groups, known as the early Wisconsin and late Wisconsin. In the first group the moraines form a rudely concentric series, which are well displayed in the northeastern part of Illinois, but are largely overridden by the moraines and drift sheets of the latter group in districts further east. The outer border of the second, or late, Wisconsin group is so discordant with the moraines of the first group that there seems in this feature alone sufficient reason for separation.

The several morainic systems of the early Wisconsin group are taken up in succession from earliest to latest, the distribution, relief, range in altitude, surface contours, thickness and structure of the drift, and the character of the outwash being considered. In connection with each morainic system the associated till-plains are discussed, attention being given to the surface features and to the structure and thickness of the drift. In northern Illinois the several morainic systems are merged into a composite belt so complex that it is difficult to trace the individual members.

The several moraines and their associated sheets of till do not appear to be separated by intervals so wide as are found between the Illinoian and the Iowan or the Iowan and Wisconsin drift sheets. Indeed, instances of the oceurrence of a soil or a weathered zone between Wisconsin sheets are very rare. There may, however, have been considerable oscillation of the ice margin.

Chapter $\mathrm{X}$ considers in like manner the late Wisconsin drift sheets. The basis for separation from the early Wisconsin is first eonsidered, after which the several morainic 
systems and their associated till-plains are taken up in order as in the discussion of the early Wisconsin drift.

In Chapter XI, the Chicago outlet and beaches of Lake Chicago are described. That a body of water once extended over the low districts bordering the southern end of Lake Michigan and discharged southwestward to the Des Plaines and thence into the Illinois river has been recognized since the early days of settlement, and several papers discussing the beaches and outlet have appeared. The latter has long been known as the Chicago Outlet, because it led away from the site of that city. The lake has recently been given a name in harmony with that of the outlet (Lake Chicago).

The influence of the drift on drainage systems and drainage conditions is discussed in detail in the twelfth chapter. It is shown that many drainage systems are entirely independent of the preglacial lines, while others are independent only in part, a considerable part of their courses being along the lines of old valleys. The development of drainage systems is shown to be much further advanced on the Iowan and Illinoian drift sheets than on the Wisconsin. This is found to be due to differences in age and not to natural advantages: for discharge. The Wisconsin is, on the whole, more favored by uneven surface for the rapid development of drainage lines than the Illinoian. The several drainage systems are discussed in considerable detaii.

Following is Chapter XIII, on the average thickness of the drift in Illinois. Illinois affords an especially good opportunity for the estimate of the thickness of the drift, because of the large number of well sections obtained, and because of the comparative smoothness of the region.

An attempt is made to estimate the part contributed by each ice invasion, but the data prove to be scarcely complete enough for a good estimate. It is found that the general thickness within the limits of the Wisconsin drift is 40 to 45 . feet greater than in the portion of the state outside.

There are two special chapters on the economic phases of VoL. IV. -25 
the investigation. That on the wells of Illinois aims to present all the reliable well records obtained within the state which throw light upon the deposits penetrated, as well as upon the character of the water supplies. A tabulation of sources for city water supplies is then presented, after which there appears a detailed discussion of wells, taken up by counties. The chapter on soils first discusses the sources of soil material. An attempt is then made to classify the soils according to their origin. Eight classes are recognized, as follows: Residuary soils, bowlder-clay soils, gravelly soils, sandy soils, bluff-loess soils, silts slowly pervious to water, fine silts nearly impervious, peaty or organic soils.

This great monograph is the outcome of fifteen years of ceaseless labor, and is to be followed by two others of similar character. It is one of the few really grand works which Iowa can regard as all her own. Well may she be proud of it.

Frank Leverett was born on a farm near Denmark, Iowa, March 10, 1859. His parents, Ebeneza Turner Leverett and Rowena Houston, were New Englanders who came west in childhood and became pioneer settlers in the Mississippi Valley, the father reaching Quincy, Illinois, with his parents, in 1834, and the mother, Denmark, Iowa, with her parents, in 1837. The paternal grandparents located at Quiney, Illinois, through the influence of Rev. Asa Turner, commonly known as "Father Turner," a cousin of the paternal grandmother, who settled there about 1830. Their removal from Quincy to Denmark, which occurred in 1856, was also largely due to the influence of Father Turner, who had, in 1838, settled at Denmark, as the pastor of the Congregational church. Through the labors of Father Turner and other pioneers from New England an academy was started at Denmark in 1843 , which became an active center of educational influence, which has been the means of stimulating and partly preparing many of the youths of Denmark and vicinity for work in educational lines.

The boy Frank was brought up in the atmosphere of 
this academy. After preliminary work in the public school, he entered the academy in 1872 , with an eager desire for an education. The school was then in charge of Prof. H. K. Edson, who for twenty-six years was its efficient principal. The subject of our sketch completed the scientific course in 1878, the last year of Prof. Edson's principalship.

At that time there seemed no way open for entering college and Mr. Leverett spent a year on the farm, with an intermission of four months teaching in the public school at Denmark. In the following year (1879) the new principal of Denmark Academy, Prof. G. W. Bingham, stimulated him to go on with his studies. He accordingly re-entered the academy with a view of completing the classical course preparatory to college, taking up Greek and continuing studies in Latin. The next year Prof. Bingham gave him further encouragement by employing him as the teacher of natural science in the academy. This position was held for three years, and it was during that time that he developed a special interest in geology. This led him to spend a year in Colorado, partly at Colorado College (located at Colorado Springs), and partly in travel through the interesting belt on the eastern border of the Rocky Mountains. In the summer of 1884 he returned to his native State, and in July matriculated in the Iowa Agricultural College. The remainder of that year and the next were spent completing the course in general science. Most of the time was devoted to laboratory work in zoology, chemistry, botany and physics, and it was then Mr. Leverett's aim to fit himself for a teacher's position in some educational institution. But before completing the course he had developed a special interest in glacial geology. This was partly on account of his investigation of a flowing well district north of Ames, which he made the subject of his graduating thesis. In the course of this study he opened correspondence with Mr. W J McGee, another of Iowa's illustrious men of science, and Prof. T. C. Chamberlin, both of the U. S. Geological Survey. This correspondence, which 
was begun for the purpose of getting help for a graduating thesis, led to employment on the Federal survey, and the abandonment of the plan to become a teacher.

Field work on the survey was begun under Prof. Chamberlin, near Beloit, Wisconsin, in May, 1886, with the position of Special Field Assistant. In $1890 \mathrm{Mr}$. Leverett was commissioned an Assistant U. S. Geologist by Secretary Noble, of the Department of the Interior, and still holds this position.

In the fourteen years service in the United States survey, Mr. Leverett has spent scarcely a year in field work in his native State, his studies having been mainly east of the Mississippi River. It was, however, through his work in southeastern Iowa that the relative dates of the culmination of the Keewatin and Labrador ice-fields was determined. He found that the Kansas drift sheet, formed by the Keewatin icefield at its maximum extension, is separated by a long interval from the overlapping Illinoian drift sheet, formed at the maximum extension of the Labrador ice-field. In the region of overlap, in Lee, Dẹs Moines, Henry, Louisa, Muscatine and Scott counties, Iowa, as well as in neighboring counties in Illinois, there are a soil and subsoil, strongly weathered, as well as extensive beds of peat separating the Kansan drift from the overlying Illinoian. To this soil with its attendant weathering Mr. Leverett has given the name "Yarmouth Soil and Weathered Zone," the name Yarmouth being from a village in Des Moines county, Iowa, where his attention was first called (in 1888) to this evidence of a long interglacial interval. Mr. Leverett also traced the old channel of the Mississippi across southeastern Iowa, which was occupied by that stream during the culmination of the Illinoian invasion of the Labrador ice field, the present course of the river from the vicinity of Clinton to Fort Madison being at that time some miles back under the Labrador ice sheet. He traced the southern part of this channel (in Lee county, Iowa) in 1883 , but at that time supposed it to 
be only an abandoned course of Cedar Creek, a view which he published in The Aurora (a monthly magazine issued by the literary societies of the Iowa Agricultural College) in 1894. But it was not until 1896 that he completed the tracing and found that the Mississippi River at one time crossed southeastern Iowa in a course outside the limits of the Illinoian drift sheet.

$\mathrm{Mr}$. Leverett has given his attention chiefly to glacial deposits and has considered both their economic and scientific phases. Among the economic phases are the questions of agricultural values, of the nature of the soils, and of water supplies, on both of which subjects he has made important official reports. The scientific phases include the mapping of the extent of each drift-sheet and the distribution of the moraines, eskers, kames and drumlins, as well as the influence of the drift upon the drainage systems. His studies have extended from eastern Iowa and Missouri eastward across Illinois, Indiana, Ohio, and northwestern Pennsylvania into western New York, and from the Ohio river northward to the Great Lakes. Nearly every township in this region has received his attention, much of the work being quite detailed. Mr. Leverett estimates that he has traveled fully 50,000 miles in this investigation, about one-half of which has been afoot. He finds no difficulty in walking twenty-five or thirty miles a day, and in a field season of six months he has walked not less than 3,000 miles.

In $1892 \mathrm{Mr}$. Leverett spent four months in the service of the Illinois Board of World's Fair Commissioners, during which he collected and arranged for the World's Fair an exhibit of the soils of Illinois, prepared a large wall-map to show the distribution of the soils, and also a report on the soils of the State.

Mr. Leverett's scientific publications began in 1884 with the article in The Aurora referred to above. He has since contributed numerous articles of high merit to the scientific journals. His more extended contributions to science have 
appeared in the proceedings of the learned societies and in the official publications of the national scientific bureaus.

Mr. Leverett is a member of many geological and other scientific societies. Nor is his interest confined to the natural sciences alone, for not a few of the political and social science associations have his name enrolled on their memberships.

\section{STUMPING THE TERRITORY. IN 1843.}

A. C. Dodge, of Burlington, was the Democratic candidate, and William Henry Wallace, of Mt. Pleasant, the Whig candidate for delegate to Congress in 1843. They stumped the Territory together, speaking in nearly all the twenty counties which were then organized. The following reminiscence of their visit at the county-seat of Clayton county was given by an old settler of that region, sixteen years afterward:

"Some sixty electors had gathered in a ring on the prairie, in the center of which was laid down a piece of timber, hewn on two sides. Presently the candidates rode up, alighted, took off their saddles, tied their horses head and foot, turned them out to graze, walked into the ring, and introduced themselves. Dodge took off his hat, stepped upon the stick of timber, made a polite bow, and for an hour and a half made a fine speech. I was disappointed in the man; I had heard so much about the awkward oxdriver and wood-sawyer that I expected little from him, but when his speech was concluded I set him down as no ordinary man; self-drilled, self-educated, his manner showed a man of no common intellect.

"In the midst of Mr. Wallace's eloquent speech a large snake of the blue racer species appeared in the ring, and was driven out, but appeared again. Some took its part and swore it should remain. There came near being a melee. Dodge requested order, and suggested it should be unmolested, which was acceded to, and the speeches went on." 
Copyright of Annals of Iowa is the property of State of Iowa, by \& through the State Historical Society of Iowa and its content may not be copied or emailed to multiple sites or posted to a listserv without the copyright holder's express written permission. However, users may print, download, or email articles for individual use. 